\title{
Effects of silage sealing films on fermentation dynamics of ensiled maize and nutrient utilization by Damara rams
}

\author{
N.W. Ndleleni ${ }^{1,2}$, I.M.M. Malebana ${ }^{2}$, C.J.L. du Toit ${ }^{3}$, K.A. Nephawe ${ }^{1}$, R. Meeske ${ }^{4}$, B.D. Nkosi ${ }^{2,5 \#}$ \\ ${ }^{1}$ Department of Animal Science, Tshwane University of Technology, Private Bag X680,Pretoria 0001, Staatsartillerie \\ Road, Pretoria 7 West, South Africa \\ ${ }^{2}$ Division for Animal Nutrition: Animal Production Institute, P/Bag x 2, Irene, 0062, South Africa \\ ${ }^{3}$ Department of Animal Science, University of Pretoria, South Africa \\ ${ }^{4}$ Outeniqua Research Station, W. Cape Department of Agriculture, George, South Africa \\ ${ }^{5}$ Centre for Sustainable Agriculture, Rural Development and Extension, University of Free State, Bloemfontein, South \\ Africa
}

(Received 9 October 2018; Accepted 22 November 2019; First published online 16 February 2020)

\begin{abstract}
Copyright resides with the authors in terms of the Creative Commons Attribution 4.0 South African License.
See: http://creativecommons.org/licenses/by/4.0/za

Condition of use: The user may copy, distribute, transmit and adapt the work, but must recognize the authors and the South African Journal of Animal Science.
\end{abstract}

\begin{abstract}
An experiment was conducted to evaluate the effects of two silage sealing films on whole crop maize (WCM) fermentation, aerobic stability and nutrient digestion by rams. Prior to ensiling (day 0), triplicate samples of the WCM were collected to determine dry matter, $\mathrm{pH}$, water-soluble carbohydrates (WSC), lactic acid (LA) bacterial counts and nutrient concentration. A single bunker silo was divided into eight sections that were ensiled using either a standard polyethylene film (PE) or an orange oxygen barrier (OB) Silostop film for 180 days. After 180 days of ensiling, six silage samples were collected from each replicate. Three samples were used for nutrient analysis and the other three to determine aerobic stability. Sixteen four-year-old Damara rams with an average live weight of $\pm 54 \mathrm{~kg}$ were housed individually in wooden pens $\left(2.2 \mathrm{~m}^{2}\right)$ to determine digestibility of nutrient in the silage. The digestibility study was conducted as a switchover design with four feeding phases. The silage was supplemented daily with $1 \%$ urea and fed to the rams ad libitum. Nutritional value of the silage was not $(P>0.05)$ affected by the ensiling films. The OB-ensiled maize had higher $(P<0.05) \mathrm{LA}$, lower $\mathrm{pH}, \mathrm{CO}_{2}$ production and yeast and mould populations, and lower WSC compared with the PE-ensiled maize. Dry matter intake, nutrient digestion and nitrogen balance of rams fed the silage were not affected $(P>0.05)$ by treatments. The OB film improved the fermentation and aerobic stability of WCM silage but did not influence its nutrient utilization by rams.
\end{abstract}

Keywords: cereals, digestibility, forage, rams, nitrogen, supplementation

\# Corresponding author: dnkosi@arc.agric.za

\section{Introduction}

Whole crop maize (Zea mays) is one of the most popular cereal crops for silage production because of high yield, low buffering capacity and a higher WSC concentration compared with other cereals (Densley et al., 2001). In addition, maize silage is a major forage fibre source in ruminant production systems in South Africa (Meeske \& Basson, 1998). However, maize silage has poor aerobic stability owing to a high concentration of LA and high residuals of WSC, which are the main sources of food for yeasts and other undesirable microorganisms (Moon, 1983; Canibe et al., 2014). Achieving and maintaining anaerobic conditions when maize silage is stored in bunkers is critical to successful ensiling (Bernardes et al., 2011). The preservation of maize silage usually takes place in bunker silos covered with low-density polyethylene film (PE), the principal function of the film being to seal the forage and allow anaerobic conditions to establish. Polyethylene film has been used for many years to seal bunker silos and drive-over piles because they are durable, not easily damaged by harsh environmental conditions, and are inexpensive compared with the alternatives (Bernardes et al., 2011). However, the high oxygen permeability of PE films can contribute to a low quality of silage in the top layer of horizontal silos (Borreani et al., 2007).

According to Bernardes et al. (2011), many farms in Brazil prefer horizontal silos with low construction costs and high work rates for filling and unloading. However, this design allows for large areas of the ensiled 
material to be easily exposed to air. This causes the silage to be more prone to aerobic spoilage, especially in the upper layer and near the sides of silos (Bernardes et al., 2011). This is also the case with many silage production farms in South Africa, since the use of PE films in maize silage production is common, and aerobic deterioration of the silage is apparent.

The permeability of plastic films to oxygen is a serious issue in silage production (Borreani et al., 2007). For example, the PE sealing film has been reported to have higher oxygen permeability than the OB film (Borreani et al., 2007; Dolci et al., 2011). The ability of sealing films and procedures to prevent air from infiltrating the silage during storage and feeding phases has significant effects on the quality of silages and its stability against aerobic spoilage by microorganisms (Woolford, 1989; Wilkinson \& Fenlon, 2013; Amaral et al., 2014). If there is any ingression of oxygen into the silage material during the storage period, aerobic microorganisms, especially lactic utilizing yeast, degrade the LA, which is the preservation acid (Woolford, 1989; Holmes \& Muck, 2007). A newly developed OB sealing film has reportedly produced similar results to the use of LAB silage inoculants under European conditions (Borreani et al., 2007). Research on the ensiling of WCM using sealing films in South Africa is limited, and the effects of OB sealing films may vary due to different environmental conditions (Schmidt \& Kung, 2010). The objectives of the present study were to determine the effect of $O B$ and $P E$ sealing films on whole maize silage fermentation characteristics and aerobic stability of maize silage, and to compare the nutrient utilization of maize silage produced using these films.

\section{Materials and Methods}

Maize (Zea mays) (Senkuil, Sensako, obtained in Brits, South Africa) was planted in November 2015 at ARC, Irene, South Africa, located at longitude $28^{\circ} 13^{`} \mathrm{~S}$ and latitude $25^{\circ} 55^{`} \mathrm{E}$ at an altitude of $1524 \mathrm{~m}$. The maize was harvested at the 50\% milk line stage in mid February 2016 using a Feraboli 945 precision silage chopper (Fondata Nel, Cremona, Italy) to obtain a theoretical $5 \mathrm{~mm}$ chop length. The WCM was ensiled using two tractors for compaction in a concrete silage bunker $(5.5 \mathrm{~m}$ width $\times 1.7 \mathrm{~m}$ height $\times 20.0 \mathrm{~m}$ length) and stored for 180 days.

The trial consisted of two experimental treatments, which were arranged in a randomized complete block design, namely i) a control in which $150 \mu \mathrm{m}$ thick co-extruded black conventional PE plastic sealing film weighed down with used tyres all over the film was used; and ii) an OB film (Silostop, Bruno Rimini Ltd, Italy) of $45 \mu \mathrm{m}$ thick co-extruded plastic sealing film. The OB film was constructed of two outer layers of polyethylene and a central layer of polyamide. Anti-ultraviolet close weave polypropylene nets were placed on top of the OB film to protect it from solar radiation and weighed down with 1-metre length Silostop gravel bags at the edges of the film to prevent the film and net from blowing off the silage.

The trial was conducted in one silage bunker ( $5.5 \mathrm{~m}$ width $\times 1.7 \mathrm{~m}$ height $\times 20.0 \mathrm{~m}$ length) to reduce possible variations that might result from differences in environmental conditions, bunker characteristics and silage compaction. The silage bunker was divided into eight equal parts (1.25 m each), with four replicates for each treatment. To avoid any movement of material and gases, the plastic films were overlapped at each end of the treatments. Samples were not collected within $2 \mathrm{~m}$ of the overlap (Figure 1).

At day 0 (pre-ensiling), triplicate samples of $2.5 \mathrm{~kg}$ per treatment were taken by hand from the middle of each replicate at a depth of $40 \mathrm{~cm}$ from top surface of the compacted material in the bunker. The samples were analysed for chemical composition: dry matter (DM), acid detergent fibre (ADF), neutral detergent fibre (NDF), crude protein (CP), ether extract (EE), and gross energy (GE). Water-soluble carbohydrates, pH and yeast counts were also determined. The coring holes were refilled with chopped material, and the locations that were sampled were recorded to ensure that later sampling took place within $50 \mathrm{~cm}$ of previous sampling sites. At day 180, the same sampling procedures were applied as on day 0 to determine chemical composition with $\mathrm{pH}$, LA and yeast and moulds also measured. Three-hundred-gram samples, which were sub-sampled from the $2.5 \mathrm{~kg}$ sample of day 180, were also subjected to an aerobic stability test. These samples were packed loosely in an open plastic jar, which was covered with two layers of cheesecloth and kept at $28{ }^{\circ} \mathrm{C}$. Thermocouples ( $\mathrm{T}$-type copper constantan 20-gauge wire) were placed in the geometric centre of the silage mass in each jar and also in the room where the jars were stored. Carbon dioxide production was determined as described by Ashbell et al. (1991) and $\mathrm{pH}$ and numbers of colony forming units (cfu) of yeasts and moulds were determined after the five-day exposure. 


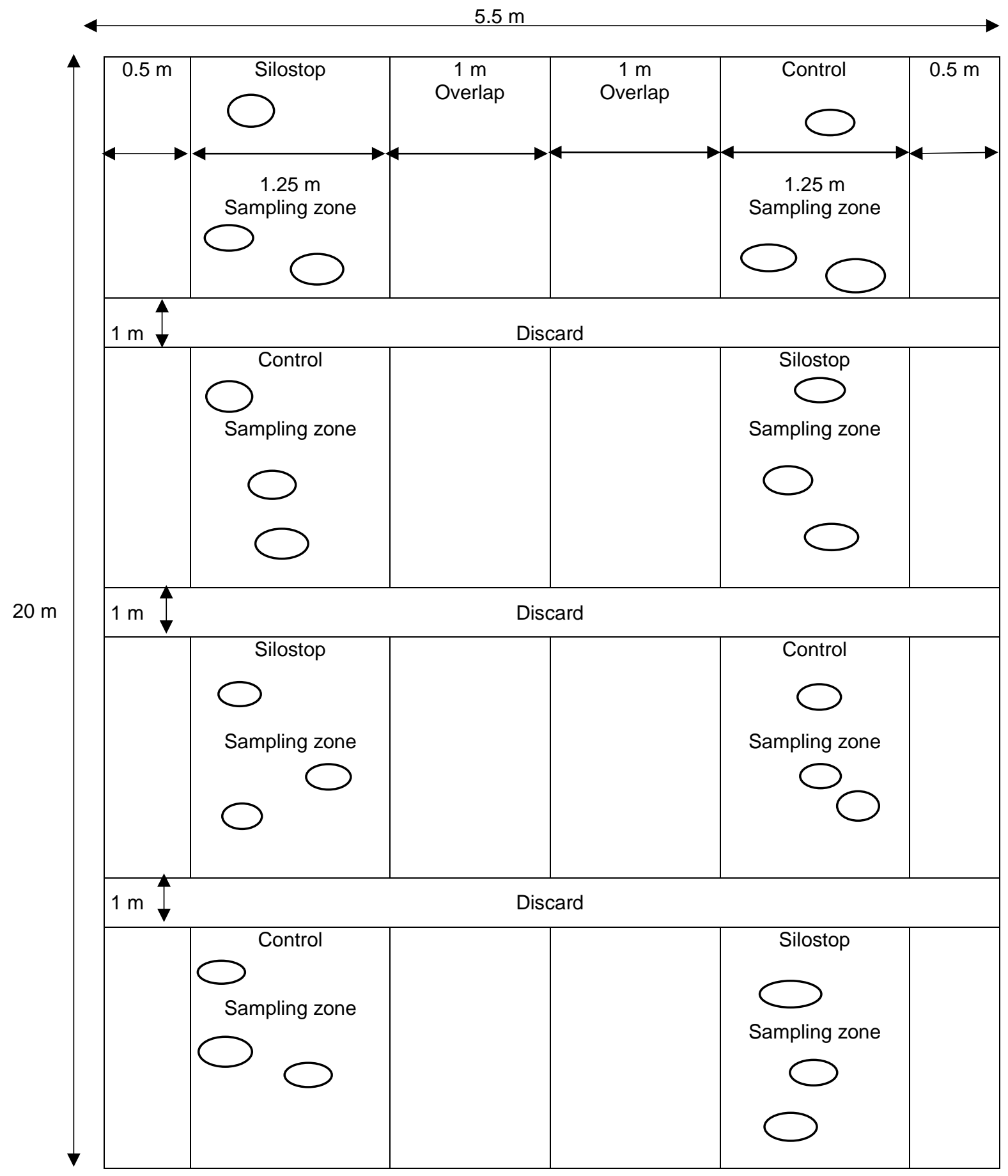

Figure 1 Overlay of the silo bunker and sampling points

After 180 days of ensiling the WCM, the top $40 \mathrm{~cm}$ of the silage in bunkers was harvested and fed to Damara rams to determine nutrient digestibility. This study design consisted of four phases, with each phase lasting 21 days. Each phase had 14 days of adaptation and seven days of urine and faecal collection. All animals were treated according to the regulations of the Animal Ethics Committee of the ARC-API (APIEC14/011). Sixteen 4-year-old Damara rams were stratified by bodyweight ( $\pm 54 \mathrm{~kg}$ live weight) and allocated to treatments. In addition, the rams were treated against internal parasites with Valbazen ${ }^{\text {(Pfizer }}$ South Africa, 85 Bute Lane, Sandton, Gauteng, South Africa), and external parasites using Deadline (Bayer Pty Ltd, 27 Wrench road, Isando, Gauteng, South Africa). Rams were housed in individual metabolic crates (1.2 m length $\times 0.74 \mathrm{~m}$ width $\times 0.92 \mathrm{~m}$ height) in an insulated well-ventilated barn. Each crate was fitted with 
an individual feeder and waterer. The average ambient temperature during the trial ranged from 24 to $28{ }^{\circ} \mathrm{C}$. The silages made using the PE and $O B$ films were fed to the rams in a switchover design (i.e. rams that were fed $\mathrm{OB}$ silage in the first phase were fed the control silage at the next phase, and vice versa, until four phases had been completed.

The silage diet fed to the rams was supplemented with $0.8 \%$ of urea. The amount of feed offered was always $10 \%$ greater than the amount that was consumed the previous day to ensure ad libitum intake, and water was freely available. Feed refusals were weighed daily before the morning feeding and DM intake was calculated from the total feed and orts. The rams were adapted to the experimental diets and metabolism crates for 14 days, followed by a seven-day urine and faeces collection period. Rams were fitted with leather harnesses and canvass bags that were attached to the back of each ram three days before the collection period. Urine was collected with a funnel fitted under the cages using $10 \mathrm{~L}$ buckets that contained $100 \mathrm{ml}$ of $100 \mathrm{~g}$ sulphuric acid $/ \mathrm{kg}$ solution, and a $10 \%$ aliquot was composited daily for each ram and frozen for $\mathrm{N}$ and energy analyses. Faeces were collected daily, recorded, and dried at $65^{\circ} \mathrm{C}$ in a forced-air oven for 72 hours. A $10 \%$ of daily collection of dried faeces was composited for each ram and frozen for analyses. Apparent digestion coefficients were calculated from quantitative feed and faecal data collected during the experiment.

The DM of pre-ensiled maize and of silages was determined by drying the samples at $60{ }^{\circ} \mathrm{C}$ until a constant mass was achieved and was corrected for loss of volatiles using the equation of Weissbach \& Strubelt (2008). After drying, the samples were ground through a 1-mm screen (Wiley mill, Standard Model 3, Arthur H. Thomas Co., Philadelphia, PA) to determine CP and GE. Crude protein was determined according to the procedure of AOAC (1990) (ID 968.06) and aNDF, ADF, and ADL were determined according to the procedures of Van Soest et al. (1991). The aNDF was determined using heat stable $\alpha-$ amylase (Sigma-Aldrich Co. Ltd., Gillingham, UK, no. A-1278) with sodium sulfite, and the ADF was determined using the Fibretec System equipment (Tecator Ltd., Thornbury, Bristol, UK). Separate samples were used to determine ADF and aNDF and both included residual ash. Gross energy in diets and faeces was determined with a bomb calorimeter (MC-1000, Energy Instrumentation, 135 Knoppieslaagte, Centurion, South Africa). Analysis of $\mathrm{N}$ in the diets, faeces and urine samples was done according to AOAC (ID 968.06, 1990).

A representative $40 \mathrm{~g}$ sub-sampled from original sample of the pre-ensiled maize and that of silage samples were taken from each treatment to determine the fermentation characteristics. Each $40 \mathrm{~g}$ silage sample ( $\mathrm{n}=3$ per replicate) was mixed with $360 \mathrm{ml}$ of distilled water in a stomacher bag, homogenized for 4 min for immediate $\mathrm{pH}$ determination with a pH meter (Thermo Orion Model 525, Thermo Fisher Scientific, Waltham, MA, USA). The sample was then filtered through Whatman no. 54 filter paper (G.I.C. Scientific, Midrand, Gauteng, South Africa). The extract was used to determine WSC and LA. The WSC was determined with the phenol-sulphuric acid method according to Dubois et al. (1956). The LA was determined with the modified colorimetric method of Pryce (1969).

The experiment was designed as a randomized complete block design with two treatments (PE and OB sealing films) that were replicated four times. Analysis of variance (ANOVA) was performed to test the difference between two treatment factors ( $P E$ and $O B$ sealing films) to determine the fermentation characteristics, chemical composition, aerobic stability and nutrient digestion of WCM silage by rams (Snedecor \& Cochran, 1967). The data were acceptably normal. Treatment means were compared using Fisher's protected t-test least significant difference (LSD) at the $5 \%$ level of significance (Snedecor \& Cochran, 1980). Data on the fermentation characteristics, chemical composition and aerobic stability of silage were analysed with the model:

$$
Y_{i j}=\mu+t_{i}+\beta_{j}+\varepsilon_{i j}
$$

Where: $Y_{i j}=$ an individual observation,

$\mu=$ the overall mean,

$t_{i}=$ the effect of the $\mathrm{i}^{\text {th }}$ treatment (PE or OB),

$\beta_{j}=$ the effect of the $j^{\text {th }}$ replicate, and

$\varepsilon_{i j}=$ the residual error.

Data on nutrient digestion by sheep were analysed with the model:

$$
Y_{i j k l}=\mu+\gamma_{i}+\pi_{j}+\tau_{k(i j)}+\xi_{l(i)}+\delta_{j} \lambda_{l(i j)}+\varepsilon_{i j k l}
$$

Where: $Y_{i j}=$ an individual observation,

$\mu=$ the overall mean,

$\gamma_{i}=$ effect of the $\mathrm{i}^{\text {th }}$ sequence, 
$\pi_{j}=$ effect of the $\mathrm{j}^{\text {th }}$ period,

$\tau_{k(i j)}=$ effect of the kth treatment nested within sequence and period,

$\xi_{k(i)}=$ random effect of the $\mathrm{I}^{\text {th }}$ ram nested within sequence,

$\delta_{j} \lambda_{m(i j)}=$ the first-order carryover effect due to treatment where $\mathrm{m}$ designates the treatment which was applied to the $\mathrm{I}^{\text {th }}$ ram in the previous period, and

$\delta_{j}=$ an indicator variable which $=0$ if period $=1$ and $=1$ if period $>1$.

\section{Results and Discussion}

Data on the chemical composition of freshly chopped WCM at pre-ensiling are shown in Table 1. The DM content of forages at ensiling has a strong influence on the rate and extent of the resulting fermentation. When silage DM content is less than $300 \mathrm{~g} / \mathrm{kg}$, conditions for clostridial bacterial activity are favourable, resulting in high DM losses and silage of low nutritional value (McDonald et al., 2010). In this study, the DM of pre-ensiled WCM was $316 \mathrm{~g} \mathrm{DM} / \mathrm{kg}$ (Table 1), suitable for ensiling. The chemical composition of the freshly chopped WCM indicates that it was harvested at an early stage of maturity, as indicated by its DM of $316 \mathrm{~g} / \mathrm{kg}$, comparable with that reported by Nkosi et al. (2009).

Table 1 Chemical composition of freshly chopped whole crop maize before ensiling $(n=12)$

\begin{tabular}{lr}
\hline Characteristic & Mean \pm SE \\
\hline DM $(g / k g)$ & $316 \pm 0.25$ \\
$\mathrm{pH}$ & $6.4 \pm 0.28$ \\
WSC g/kg DM & $119.5 \pm 0.85$ \\
CP g/kg DM & $69.6 \pm 0.32$ \\
GE MJ/kg DM & $15.6 \pm 0.09$ \\
EE g/kg DM & $1.8 \pm 0.88$ \\
ADF g/kg DM & $253.8 \pm 0.48$ \\
aNDF g/kg DM & $501.5 \pm 1.42$ \\
Yeast $/$ log 10 cfu/g & $5.75 \pm 0.64$
\end{tabular}

DM: dry matter, WSC: water-soluble carbohydrates, CP: crude protein, GE: gross energy, EE: ether extract, ADF: acid detergent fibre, aNDF: amylase treated neutral detergent fibre, cfu: colony forming units

Data on the fermentation characteristics and nutrient composition of maize silage after 180 days of ensiling are shown in Table 2. The terminal $\mathrm{pH}$ of the maize silage was similar $(P>0.05)$ among the treatments. The WSC and the yeast counts were higher $(P<0.05)$ in the maize silage produced with PE compared with OB film. However, LA production was higher $(P<0.05)$ in the OB film compared with the PE film. The nutrient composition of the maize silage did not $(P>0.05)$ differ between the two films. It is well documented that the $\mathrm{pH}$ of silage is one of the most important factors that affect silage preservation (McDonald et al., 2010). A pH range of $3.7-4.2$ is generally considered beneficial for the preservation of cereal forages (Kung \& Shaver, 2001) and that of the present study was less than 3.8, indicative of wellpreserved silage. The treatment did not affect the terminal silage $\mathrm{pH}$, which is common in maize silage, since maize have enough WSC and low buffering capacity (Meeske, 2005).

Water-soluble carbohydrates are regarded as essential substrates for growth of LAB for proper fermentation (McDonald et al., 1991). The WSC concentration of WCM at ensiling in the present study was $120 \mathrm{~g} \mathrm{WSC} / \mathrm{kg} \mathrm{DM}$, which is more than the minimum level of $60 \mathrm{~g} / \mathrm{kg}$ that is required for efficient fermentation (Lunden-Petersen \& Lindgren, 1990). However, the maize silage produced with OB film had reduced $(P$ $<0.05)$ residual WSC compared with that for silage produced with PE film. It can be assumed that the low oxygen permeability of the $O B$ created suitable conditions for maximum growth of $L A B$, which resulted to more WSC being consumed by LAB under the OB film compared with the control.

Lactic acid is the strongest of all silage acids and its high concentration will decrease the $\mathrm{pH}$ more effectively than other volatile fatty acids (McDonald et al., 2010). In the present study, more LA was produced in the silage sealed with the OB film, which is consistent with low residuals of WSC $(P<0.05)$ (Table 4). This indicates that the OB film created an anaerobic environment that is suitable for the growth of LAB to convert more WSC to LA (Borreani et al., 2007). 
Table 2 Fermentation characteristics and nutrient composition of whole crop maize silage collected at the top $40 \mathrm{~cm}$ after 180 days of ensiling sealed with either standard polyethylene film or an orange oxygen barrier Silostop film $(n=12)$

\begin{tabular}{|c|c|c|c|c|}
\hline \multirow{2}{*}{ Fermentation characteristics } & \multicolumn{2}{|c|}{ Treatments $^{1}$} & \multirow{2}{*}{ SE } & \multirow{2}{*}{$P$-value } \\
\hline & PE & OB & & \\
\hline $\mathrm{pH}$ & 3.8 & 3.7 & \pm 0.08 & 0.317 \\
\hline WSC g/kg & 15.9 & 11.4 & \pm 0.31 & 0.002 \\
\hline Lactic acid g/kg & 66.6 & 73.6 & \pm 1.12 & 0.022 \\
\hline Yeast $\log _{10} \mathrm{cfu} / \mathrm{g}$ & 5.8 & 3.8 & \pm 1.72 & 0.046 \\
\hline \multicolumn{5}{|l|}{ Nutrient composition } \\
\hline DM g/kg & 303.8 & 363.2 & \pm 8.53 & 0.016 \\
\hline CP g/kg & 80.8 & 81.7 & \pm 2.30 & 0.379 \\
\hline GE MJ/kg & 16.1 & 15.9 & \pm 0.98 & 0.246 \\
\hline $\mathrm{EE} \mathrm{g/kg}$ & 2.3 & 2.3 & \pm 0.19 & 0.147 \\
\hline aNDF g/kg & 457.0 & 436.0 & \pm 0.95 & 0.048 \\
\hline ADF g/kg & 323.0 & 244.1 & \pm 3.18 & 0.017 \\
\hline
\end{tabular}

${ }^{1} \mathrm{PE}$ : polyethylene sealing film, OB: orange oxygen barrier Silostop sealing film

DM; dry matter; WSC, water soluble carbohydrates; CP, crude protein; GE, gross energy; EE, ether extract; ADF, acid detergent fibre; aNDF, amylase treated neutral detergent fibre

Lower concentrations of aNDF in silages, compared with the original herbage concentrations, reflect the extent of breakdown primarily of hemicellulose during ensiling. This breakdown yields additional substrate for the fermentation process. Hemicellulose can also be degraded through hydrolysis by organic acids that are produced during fermentation or that can be applied with silage additives (McDonald et al., 1991). The fibre fractions of the WCM were reduced with ensiling (see Tables 1 and 2), which reflects the degradation of fibre to release sugar to be consumed by LAB. However, differences between treatments were not significant post ensiling.

Data on the aerobic stability of maize silage produced with either PE or OB films are shown in Table 3. The $\mathrm{pH}, \mathrm{CO}_{2}$ production, and populations of yeast and moulds were lower $(P<0.05)$ in the maize silage produced with OB film compared with those produced with PE film. In a warm climate, such as that of South Africa, WCM silage is susceptible to accelerated aerobic deterioration. Aerobic yeasts that metabolize LA to carbon dioxide and water (producing heat) are most active between $20^{\circ} \mathrm{C}$ and $30{ }^{\circ} \mathrm{C}$ (Ashbell et al., 2002). Silage that has spoiled is undesirable owing to an increased risk of proliferation of potentially pathogenic or undesirable microorganisms that negatively affect animal performance (Driehuis et al., 1999; Trevisi et al., 2003).

The high $\mathrm{pH}$ of the silage that was produced using $\mathrm{PE}$ film compared with the silage that was produced with the OB film (Table 3 ) was probably caused by high yeast populations, which were present in greater numbers owing to the high permeability of the PE sealing film to oxygen (Dolci et al., 2011). High yeast concentrations in silage are known to initiate and accelerate its aerobic deterioration (McDonald et al., 1991; Driehuis et al., 2001). Several studies (Borreani et al., 2007; Muck \& Holmes, 2009) have demonstrated the consequences of high concentrations of oxygen in silage because of the high permeability of the sealing film to oxygen, resulting in DM and nutrient losses and accumulations of pathogens. Dolci et al. (2011) compared maize silage produced with either OB or PE film, and reported reduced silage aerobic stability in silage produced under PE film compared with that produced under OB film. The results of the present study are thus consistent with the previous results of Dolci et al. (2011). Production of $\mathrm{CO}_{2}$ from silage during the aerobic stability test is an indication of the levels of yeasts and moulds in the silage (Woolford, 1989; Ashbell et al., 1991). According to Weinberg et al. (1993), silages with higher residual of WSC concentrations are less stable when exposed to air. Here, WCM silage that was produced with PE film had a higher residual WSC concentration; hence its aerobic stability was impaired deemed compared with that produced with $\mathrm{OB}$ film. Silages with yeast concentrations greater than $10^{5} \mathrm{cfu} / \mathrm{g}$ are prone to deteriorate 
on exposure to air (McDonald et al., 1991). In the present study use of the PE sealing film led to a yeast population of $10^{5} \mathrm{cfu} / \mathrm{g}$.

Table 3 Effects of standard polyethylene film or an orange oxygen barrier Silostop sealing film on the aerobic stability of maize silage after five days' aerobic exposure $(n=12)$

\begin{tabular}{|c|c|c|c|c|}
\hline \multirow{2}{*}{ Indicators of aerobic stability } & \multicolumn{2}{|c|}{ Treatments $^{1}$} & \multirow{2}{*}{ SE } & \multirow{2}{*}{$P$-value } \\
\hline & PE & OB & & \\
\hline $\mathrm{DM} \mathrm{g} / \mathrm{kg}$ & 218.0 & 273.0 & \pm 1.79 & 0.001 \\
\hline $\mathrm{pH}$ & 6.8 & 5.8 & \pm 0.13 & 0.010 \\
\hline $\mathrm{CO}_{2} \mathrm{~g} / \mathrm{kg}$ & 58.5 & 38.2 & \pm 3.33 & 0.023 \\
\hline Yeast \& moulds $\log _{10} \mathrm{cfu} / \mathrm{g}$ & 8.43 & 4.21 & \pm 0.84 & 0.008 \\
\hline
\end{tabular}

${ }^{1}$ PE: polyethylene sealing film, OB: orange oxygen barrier Silostop sealing film

$\mathrm{DM}$ : dry matter; $\mathrm{CO}^{2}$, carbon dioxide

Data on intake, nutrient digestion and $\mathrm{N}$ retention in rams fed maize silage are shown in Tables 4 and 5 , respectively. No significance $(P>0.05)$ differences occurred in the intake, nutrient digestion and $\mathrm{N}$ retention in rams fed maize silage that was produced with using either $\mathrm{PE}$ or OB sealing film.

Table 4 Effects of sealing ensiled chopped whole crop maize with a standard polyethylene film or an orange oxygen barrier Silostop film on daily feed intake and apparent nutrient digestibility by Damara rams

\begin{tabular}{lrrrr}
\hline \multirow{2}{*}{ Intake } & \multicolumn{2}{c}{ Treatments $^{1}$} & & SE \\
\cline { 2 - 3 } & PE & OB & & \\
\hline DM & 1444.0 & 1089.0 & \pm 0.62 & 0.289 \\
CP & 121.2 & 130.3 & \pm 0.17 & 0.295 \\
GE MJ/day & 191.3 & 182.0 & \pm 0.17 & 0.350 \\
EE & 59.8 & 54.6 & \pm 0.22 & 0.911 \\
NDF & 507.0 & 507.3 & \pm 0.17 & 0.837 \\
ADF & 278.6 & 305.6 & \pm 0.17 & 0.204 \\
Apparent digestibility $(\mathrm{g} / \mathrm{g})$ & & & \\
DM & 701.1 & 673.7 & \pm 0.17 & 0.285 \\
CP & 647.5 & 625.4 & \pm 0.17 & 0.966 \\
ADF & 586.6 & 605.9 & \pm 0.17 & 0.157 \\
NDF & 585.0 & 549.3 & \pm 0.17 & 0.488
\end{tabular}

${ }^{1} \mathrm{PE}:$ polyethylene sealing film, OB: orange oxygen barrier Silostop sealing film

DM: dry matter, CP: crude protein, GE: gross energy EE: ether extract, ADF: acid detergent fibre NDF: neutral detergent fibre

It is generally known that maize silage has a low CP concentration. Hence, dietary supplementation of $\mathrm{CP}$ should be done to meet the daily CP requirements of ruminants fed maize silage. In this present study, $0.8 \%$ of urea was added to the daily ration of the rams, based on the daily intake of each ram. However, silage treatments did not differ in the intake, DM, CP, NDF and ADF digestion and N utilization by rams (Table 4 and 5). This might be attributed to the similar nutrient composition of the two silages. 
Table 5 Effects of sealing ensiled chopped whole crop maize with a standard polyethylene film or an orange oxygen barrier Silostop film on nitrogen intake and retention in Damara rams fed whole crop maize silage

\begin{tabular}{lrrrrr}
\hline \multirow{2}{*}{ Components of nitrogen (N) flux } & \multicolumn{2}{c}{ Treatments $^{1}$} & & SE & P-value \\
\cline { 2 - 3 } & PE & OB & & & \\
\hline N intake, g/d & 19.70 & 21.60 & \pm 0.160 & 0.294 \\
Faecal N, g/day & 6.27 & 6.87 & \pm 0.166 & 0.587 \\
Urinary N, g/day & 4.45 & 4.42 & \pm 0.168 & 0.466 \\
N retention, g/day & 8.99 & 10.35 & \pm 0.170 & 0.193 \\
N retention, \% & 46.4 & 48.2 & \pm 0.160 & 0.394 \\
\hline
\end{tabular}

${ }^{1}$ PE: polyethylene sealing film, OB: orange oxygen barrier Silostop sealing film

\section{Conclusion}

Fermentation characteristics and aerobic stability of maize silage were improved with the use of the OB sealing film compared with the PE sealing film. However, these effects did not lead to improved nutrient concentration, or digestibility and $\mathrm{N}$ balance in rams fed the two silages. Thus, use of the OB sealing film could improve the efficiency of maize silage production compared with the use of PE sealing film under South African conditions. The cost effectiveness of using OB film for the production of maize silage under South African conditions should be determined.

\section{Acknowledgements}

The authors wish to thank the National Research Foundation for funding this project. The assistance of Mr L. Maesela in caring for the experimental animals and Ms Cynthia Ngwane for statistical design are appreciated.

\section{Authors' Contributions}

BDN, RM, IMM, CJLT, NWN and KAN worked on the original report and data analysis. BDN, RM, IMM and NWN worked on the study design, execution and data collection. NWN, BDN and IMM worked on the manuscript preparation.

\section{Conflict of Interest Declaration}

There is no conflict of interest associated with this manuscript.

\section{References}

Amaral, F., Santos, M.C., Daniel, J. \& Nussio, L.G., 2014. The influence of covering methods on the nutritive value of corn silage for lactating dairy cows. R. Bras. Zootec. 43, 471-478.

AOAC, 1990. Official methods of analysis. (15th ed.) Association of Official Analytical Chemists, Washington DC, USA.

Ashbell, G., Weinberg, Z.G., Hen, Y. \& Filya, I., 2002. The effects of temperature on the aerobic stability of wheat and corn silages. J. Ind. Microbiol. Biotechnol. 28, 261-263.

Ashbell, G., Weinberg, Z.G., Azriel, A., Hen, Y. \& Horev, B., 1991. A simple system to study the aerobic deterioration of silages. Can. Agric. Eng. 33, 391-393.

Bernardes, T.F., Nussio, L.G. \& do Amaral, R.C., 2011. Top spoilage losses in maize silage sealed with plastic films with different permeabilities to oxygen. Grass Forage Sci. 67, 34-42.

Bolsen, K.K., 2006. Silage management: common problems and their solution. In: Proceedings of Tri-State Dairy Nutrition Conference, Fort Wayne, Indiana, USA. 25-26 April 2006. Pp. 83-93

Borreani, G., Tabacco, E. \& Cavallarin, L., 2007. A new oxygen barrier film reduces aerobic deterioration in farm-scale corn silage. J. Dairy Sci. 90, 4701-4706.

Canibe, N., Kristensen, N.B., Jensen, B.B. \& Vils, E., 2014. Impact of silage additives on aerobic stability and characteristics of high-moisture maize during exposure to air, and on fermented liquid feed. J. Appl. Microbiol. $116,747-760$.

Densley, R., Miller, D. \& Kolver, E.S., 2001. Breaking the feed barrier using maize. Proceedings of the New Zealand Grassland Association, 63, 289-293.

Dolci, P., Tabacco, E., Cocolin, L. \& Borreani, G., 2011. Microbial dynamics during aerobic exposure of corn silage stored under oxygen barrier or polyethylene films. Am. Societ. Microbiol. 77, 7499-7507.

Driehuis, F., Oude Elferink, S.J.W.H. \& Van Wikselaar, P.G., 2001. Fermentation characteristics and aerobic stability of grass silage inoculated with Lactobacillus buchneri, with or without homofermentative lactic acid bacteria. Grass Forage Sci. 56, 330-343.

Driehuis, F., Elferink, S.J.W.H. \& Spoelstra, S.F., 1999. Anaerobic lactic acid degradation during ensilage of whole crop maize inoculated with Lactobacillus buchneri inhibits yeast growth and improves aerobic stability. J.Appl. Microbiol. 87, 583-594. 
Dubois, M., Giles, K.A., Hamilton, J.K., Rebes, P.A. \& Smith, F., 1956. Colorimetric method for determination of sugars and related substances. Anal. Chem. 28, 350-356.

Holmes, B.J. \& Muck, R.E., 2007. Packing bunkers and pile to maximise forage preservation. In: Proceedings of the 6th International Dairy Housing Conference, Minneapolis, 16-18 June 2007. St Joseph, M.I. USA. Am. Societ. Agril. Biol. Eng. Publication 701P0507e.

Kung Jr., L. \& Shaver, R., 2001. Interpretation and use of silage fermentation analysis reports. University of Wisconsin, Madison, WI, USA. Focus on Forage 3, 1-5.

Lunden-Pettersson, P.K. \& Lindgren, S., 1990. The influence of the carbohydrate fraction and additives on silage quality. Grass Forage Sci. 45, 223-233.

McDonald, P., Henderson, A.R. \& Heron, S.J.E., 1991. The biochemistry of silage. Chalcombe, Marlow, Buckinghamshire, UK. p. 109.

McDonald, P., Edwards, R.A., Greenhalgh, J.F.D., Morgan, C.A., Sinclair, L.A. \& Wilkinson, R.G., 2010. Evaluation of foods: Energy content of foods and energy partition within the animal. In: Animal Nutrition (7th ed.) Chap. 11. pp 254-280.

Meeske, R., 2005. Silage inoculants: Do they make a difference? South Africa J. Anim. Sci. 6: 49-55.

Meeske, R. \& Basson, H.M., 1998. The effect of lactic acid bacterial inoculant on maize silage. Anim. Feed Sci. Technol. 70, 239-247.

Moon N.J., 1983. Inhibition of the growth of acid tolerant yeast by acetate, lactate and propionate and their synergistic mixtures. J. Appl. Bacteriol. 55, 454-460.

Muck, R.E. \& Holmes, B.J., 2009. Influence of cover type on silage quality in bunker silos. In: Proceedings of 15th International Silage Conference. Madison, USA. pp. 277-278.

Nkosi, B.D., Meeske, R., Palic, D., Langa, T., Leeuw, K-K. \& Groenewald, I.B., 2009. Effects of ensiling whole crop maize with bacterial inoculants on the fermentation, aerobic stability and growth performance of lambs. Anim. Feed Sci. Technol. 154, 193-203.

Pryce, J.D., 1969. Modification of the Barker \& Summerson method for the determination of lactic acid. Analyst 94, 11511152.

Schmidt, R.J. \& Kung Jr, L., 2010. The effects of lactobacillus buchneri with or without a homolactic bacterium on the fermentation and aerobic stability of corn silages made at different locations. J. Dairy Sci. 93, 1616-1624.

Snedecor, G.W. \& Cochran, W.G. 1967. Statistical methods (6th ed.). Iowa State University Press, lowa, USA. Chap. 1012, 258-377.

Snedecor, G.W. \& Cochran, W.G., 1980. Statistical methods (7th ed.). lowa State University Press, lowa, US. p. 507.

Trevisi, P., Bani, P. \& Bertoni, G., 2003. Effects of use of maize-silage with low aerobic stability on performance of lactating dairy cows. Vet Res Commun. 27, 273-275.

Van Soest, P.J., Robertson, J. B. \& Lewis, B. A., 1991. Methods of dietary fiber, neutral detergent fiber, and non-starch polysaccharides in relation to animal nutrition. J. Dairy Sci. 74, 3583-3597.

Weinberg, Z.G., Ashbell, G., Hen, Y. \& Azreli, A., 1993. The effect of applying lactic acid bacteria at ensiling on the aerobic stability of silages. J. Appl. Bacteriol. 75, 512-518.

Weissbach, F.E. \& Strubelt, C., 2008. Correcting the dry matter content of maize silages as a substrate for biogas production. 63 Landtechnik 2, 82-83.

Wilkinson, J.M. \& Fenlon, J.S., 2013. A meta-analysis comparing standard polyethylene and oxygen barrier film in terms of losses during storage and aerobic stability of silage. Grass Forage Sci. 69, 385-392.

Woolford, M.K., 1989. The detrimental effects of air on silage. J. Appl. Bacteriol. 68, 101-116. 